\title{
History of the Indiana Geological and Water Survey
}

\author{
Deborah A. DeChurch, editor \\ Indiana Geological and Water Survey, Indiana University, Bloomington, Indiana
}

Received 02/03/2020

Accepted for publication 03/18/2020

Published 09/15/2020

Suggested citation: DeChurch, D. A., ed., 2020, History of the Indiana Geological and Water Survey: Indiana Geological and Water Survey, Indiana Journal of Earth Sciences, v. 2. DOI 10.14434/ijes.v2i0.29171

The early years of the Survey's history (1837-1986) is taken, almost verbatim, from an article written by John B. Patton (Director and State Geologist from 1959-86) (Patton, 1988). Information from later years is from various sources: the Hester years from an unpublished piece by John R. Hill (Indiana Geological Survey Geologist and Assistant Director from 1970 to 2007) and the Steinmetz years from the reminiscences of John C. Steinmetz (Director, 1998-2015). It also includes various facts taken from Landmarks in Indiana Geology- $A$ Timeline, an online visual history by Henry H. Gray (2018). These various pieces were edited and expanded upon by Deborah A. DeChurch, with the assistance of Nancy R. Hasenmueller, Barbara T. Hill, Jennifer R. Lanman, Polly R. Sturgeon, and Todd A. Thompson. We also relied upon the institutional memories of other staff members. 


\section{HISTORICAL SEQUENCE OF ORGANIZATIONAL NAME:}

1837-1839 Geological Survey of the State of Indiana

1851-1853 Geological Agent, State Board of Agriculture

1859-1869 Geological Survey, State Board of Agriculture

1869-1879 Department of Geology and Natural Science, State Board of Agriculture

1879-1881 Department of Statistics and Geology, State Board of Agriculture

1881-1889 Department of Geology and Natural History

1889-1919 Department of Geology and Natural Resources, Division of Geology and Natural Science

1919-1947 Division of Geology, Indiana Department of Conservation

1947-1965 Geological Survey, Indiana Department of Conservation

1965-1993 Geological Survey, Bureau of Water and Mineral Resources, Department of Natural Resources

1993-2017 Indiana Geological Survey, Indiana University

2017-present Geological and Water Survey, Indiana University

\section{NAMES AND TITLES OF ORGANIZATIONAL DIRECTORS AND DATES SERVED:}

1837-1839 David Dale Owen, Geologist for the State of Indiana

1851-1854 Ryland Thomas Brown, Geological Agent

1859-1860 David Dale Owen, State Geologist

1860-1861 Richard Owen, State Geologist

1869-1879 Edward Travers Cox, State Geologist

1879-1885 John Collett, State Geologist

1885-1888 Maurice Thompson, State Geologist

1888-1894 Sylvester Scott Gorby, State Geologist

1895-1910 Willis Stanley Blatchley, State Geologist

1911-1918 Edward Barrett, State Geologist

1919-1936 William Newton Logan, State Geologist

1936-1945 Ralph Emerson Esarey, State Geologist

1945-1959 Charles Frederick Deiss, State Geologist

1959-1986 John Barratt Patton, Director and State Geologist

1986-1998 Norman Curtis Hester, Director and State Geologist

1998-2015 John Charles Steinmetz, Director and State Geologist

2015-present Todd Alan Thompson, Director and State Geologist
HISTORICAL SEQUENCE OF ORGANIZATIONAL LOCATION:

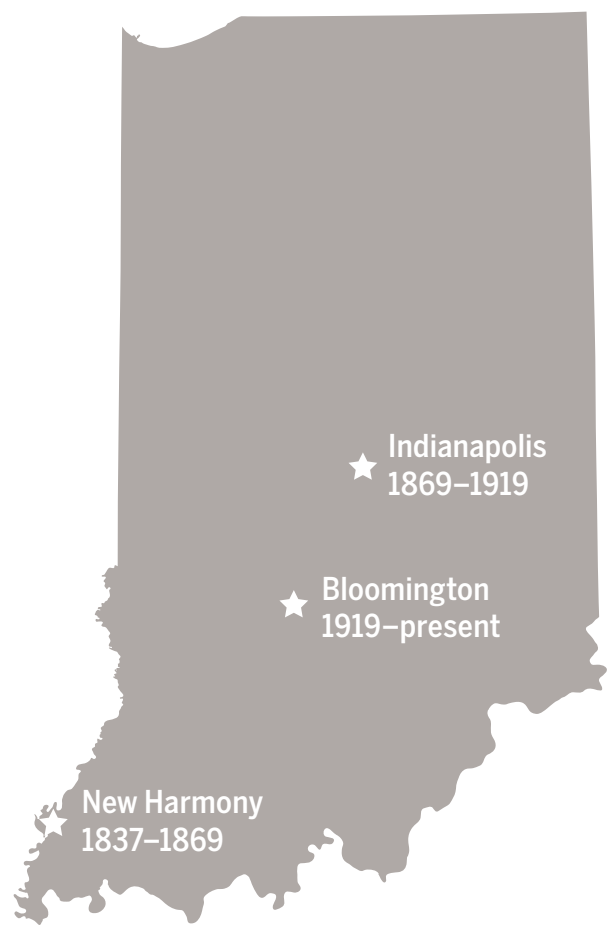




\section{THE EARLY YEARS}

On February 6, 1837, in the 20th year after Indiana achieved statehood, the state legislature approved an act that began with the words:

Be it enacted by the General Assembly of the State of Indiana, That the Governor be and is hereby authorized and required annually hereafter to appoint and commission a person of talents, integrity, and suitable scientific acquirements as Geologist for the State of Indiana, who shall receive in consideration of his faithful performance of his duties an annual salary not exceeding \$1,500.00 and necessary expenses not to exceed $\$ 250.00$, to be paid as the salaries of other civil officers of the State.

Where to find a person of talents, integrity, and suitable scientific acquirements in any sparsely populated frontier state of that era might have proved to be a problem, but Indiana was the home of a person so well fitted for the role that we must wonder whether the position was not created to utilize his talents. The man was David Dale Owen, one of the sons of Robert Owen, who had purchased the town of New Harmony on the Wabash River in Posey County in 1824.

And how did it happen that David Dale Owen, as well as his brother Richard, became geologists? Surely we must attribute the circumstance in considerable part to the fact that William Maclure had, in 1825, become a partner with Robert Owen in the ownership of New Harmony.

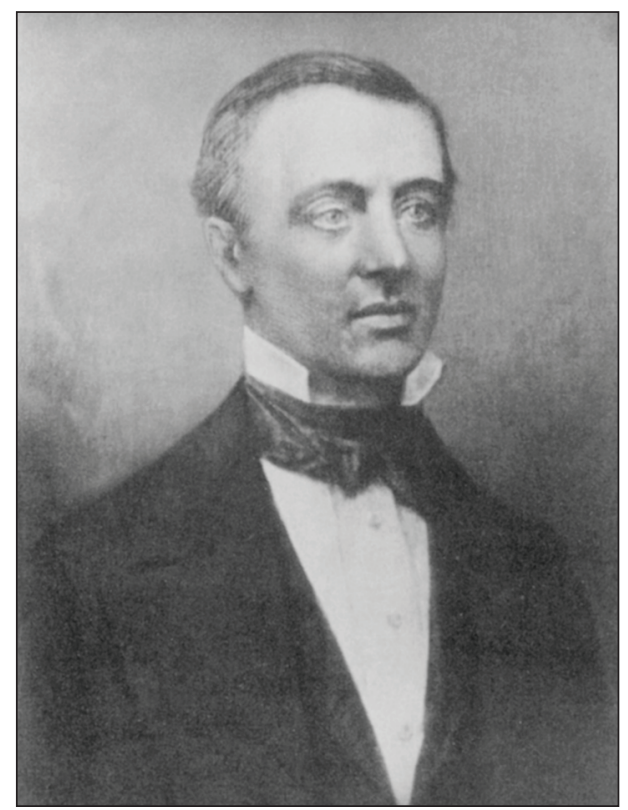

David Dale Owen, Geologist for the State of Indiana, 1837-39; State Geologist, 1859-60.
Self-trained in geology, Maclure accumulated a fortune in business at an early age and was then able to devote years to his avocations-geology and applied public education - with such success that he has been referred to as the father of American geology and the William Smith of America, and the first chapter of Merrill's volume (1924) The First 100 Years of American Geology is entitled "The Maclurian Era, 1785-1819."

Maclure's reputation was established before he came permanently to North America. His geologic investigations and publications in this country, including some of the first regional maps showing the eastern portion of the continent, added to his luster, but this work preceded his investment in New Harmony. He continued to publish, mostly on topics of global scale, through 1832, but his work did not emphasize the geology of midwestern North America, although the last two of his American papers were published in New Harmony.

It was Maclure, without doubt, who attracted other eminent geologists to New Harmony and gave to the New Harmony cultural and scientific movement a geologic flavor that was unique in the New World. The most lasting impact that Maclure had on American geology may well have been the inspiration that he afforded to the then-young David Dale Owen, a person of great talent but without specific direction of interest until about 1835, after Maclure's departure from New Harmony. Maclure himself, his immense collections, and the eminent scientists that he attracted to New Harmony must have been major factors in Owen's decision to become a geologist. For this purpose, he entered medical school at Cincinnati and received the M.D. degree, apparently with no intent of becoming a practicing physician but because he regarded medical training as the best method of filling the gaps in his scientific knowledge. He had already some expertise in chemistry, and he thought it necessary to master physiology and anatomy in order to work with fossils that were the key to deciphering the geologic record in the Midwest. In 1836, apparently between sessions of his medical training, Owen assisted Dr. Gerard Troost, then State Geologist of Tennessee, in a survey of that state. Troost, a Hollander, had spent a period in New Harmony during 1825 to 1827 , when Maclure was there.

In the course of horseback traverses in 1837, Owen determined the stratigraphic succession of the bedrock (Owen, 1838, p. 11-19) and accurately placed the units in relation to the time scale that was evolving for systemic nomenclature in Great Britain. He correctly separated the systems that later became in America the Mississippian and Pennsylvanian, and he distinguished between the rocks that form the present-day Ordovician 
and Silurian Systems, even though the Ordovician System was not proposed by Lapworth until 1879. To accompany his reports, Owen prepared in 1838 an outline map of the geology of Indiana that was never published but was deposited in the State Library, from which it must have been lost or taken before many years had passed, as there appears to be no certain reference to it except Owen's own. In the report for 1838 (Owen, 1839, p. 40-45) he described what he termed "The accompanying map" in sufficient detail to establish the fact that the boundaries shown must have been essentially the same as those shown on a map printed as part of an Owen paper published in England (1846). A reprinting of the report for 1838 (Owen, 1859, p. 53) carries an asterisk after the words "The accompanying map..." and the footnote "The original map, here referred to, was deposited in the State Library, but has not been published." Further reference to the 1838 Owen map may have been intended by Brown (1854) in the words, "The labors of Dr. Owen, some years ago, have furnished us with an outline map of the Geology of the State, so that the lines of outcrop of the several formations are pretty accurately defined."

But by then, Owen's 1846 map, which covered much territory outside Indiana, was available, and so we cannot be certain that Brown's comment affords evidence that Owen's earliest map of the state was still in the State Library.

That Owen was able to tie the European and American continents together stratigraphically, carrying on precedents set by Maclure and Samuel George Morton, may not seem today to have been a notable accomplishment, but we are speaking of an era in which much of the stratigraphic work was done in a manner that did not offer any correlation between the rocks described and strata elsewhere. Stratigraphic units were most commonly named at the time by their lithologic characteristics, and Owen's were no exception, but their boundaries accorded with those of the classic British systems. His coal formation was the equivalent of the Upper Carboniferous of Great Britain, now the Pennsylvanian System in North America. The map correctly separated British Lower Carboniferous, which became our present Mississippian System, from the underlying Devonian and Silurian Systems of the time. A boundary that encircled the crest of the Cincinnati Arch delineated the top of the then Lower Silurian, which became the Ordovician System. In establishing the time relationship of these units with the classic British type sections, Owen extended traditional stratigraphic treatment into a region more than 6,000 miles from the home base and thus furthered the concept of global chronostratigraphy.
The Fenton and Fenton volume Giants of Geology (1942, p. 163) commented unfavorably on the tendency for geologists of that time to restrict their interests to the collection and identification of fossils, but they quoted from the first Owen report $(1838$, p. 4) as follows:

I have considered it my duty, while surveying a country so new as ours, to remember, that a State just settling, is like a young man starting in life, whom it behooves to secure to himself a competency, before he indulges in unproductive fancies. I have considered it the most important object, to search out the hidden resources of the State, and open new fields of enterprise to her citizens. That object effected, time enough will remain to institute inquiries (which a liberal policy, forbids us to overlook) of a less productive and more abstract character; inquiries which are interesting in a scientific, rather than a commercial, point of view.

The Fentons continued, "a sane as well as practical rule, and one which made the man who framed it America's first great economic geologist."

Owen correctly predicted $(1838$, p. 26$)$ that commercial coal would not be found beneath the uppermost of the limestones that are now classified as Mississippian in age. He called attention to both limestone and sandstone suitable for building stone, to clays and shales usable for ceramic ware, to natural cement rock, to iron ores that would suffice for the small-scale recovery operations of that day, to rock units that could be fashioned into whetstones and rotary grindstones, and to sand and gravel deposits. Owen did not actually discover all of these mineral resources, as most had already been noted and used, but he placed the materials into a geologic order that permitted a scientific approach to their location.

The Owen survey failed to mention only two of the resources that have contributed in any substantial measure to the mineral economy of the state during the ensuing 150 years, petroleum - and we should remember that his work preceded the drilling of the Drake well at Titusville, Pennsylvania, by more than 20 years - and gypsum, which does not appear at the surface in Indiana and was not recognized as having economic potential until the 1950s.

Political support was strong for continuation of the Indiana survey, but the opposition was strong also. Not until two days before the end of the 1839 legislative session was a bill for continuation approved, and it was amended to cover only one year instead of the proposed three years. Although the bill passed in February 1839, the governor did not immediately appoint Owen for continued service, and reappointment was not offered until June; by then David Dale Owen had become interested in, and was fairly assured of receiving, appointment as a geologist for the federal government. He 
declined the Indiana appointment. State-supported geologic investigations in Indiana virtually ceased for a period of 20 years, except for employment from 1851 to 1853 of Ryland T. Brown as Geological Agent for the State Board of Agriculture and a single published geologic report (Brown, 1854) that resulted from the assignment.

Certainly the geologic activities of David Dale Owen and a number of his professional colleagues, including his brother Richard, did not cease, and New Harmony remained a center for geologic work, but most of it did not concern Indiana geology (Hendrickson, 1943; Patton, 1979, 1987; Patton, Millbrooke, and Nelson, 1983).

Maclure had died in Mexico in 1840 and, at the request of Maclure's heirs, Owen spent some time classifying the huge Maclure collection, to which he added many items from his own fieldwork. He made a lengthy collecting trip along the Ohio River in 1841, and the resulting 2 tons of material exceeded the capacity of the building that he was then using as a laboratory, the second in a series. Maclure's sister then gave him a large building that had been constructed of sandstone and brick by the Harmonists for use as a granary and that has been called the "Old Fort." He remodeled it extensively, and it came to be known as "The Laboratory." It contained storerooms, workrooms, and a large lecture hall, as well as exhibit space. In 1846 the noted British geologist Sir Charles Lyell, with Lady Lyell, was the guest of the Owens, and Sir Charles "spent much time in Owen's laboratory and carefully inspected the fossil and mineral cabinets. In company with Owen he visited

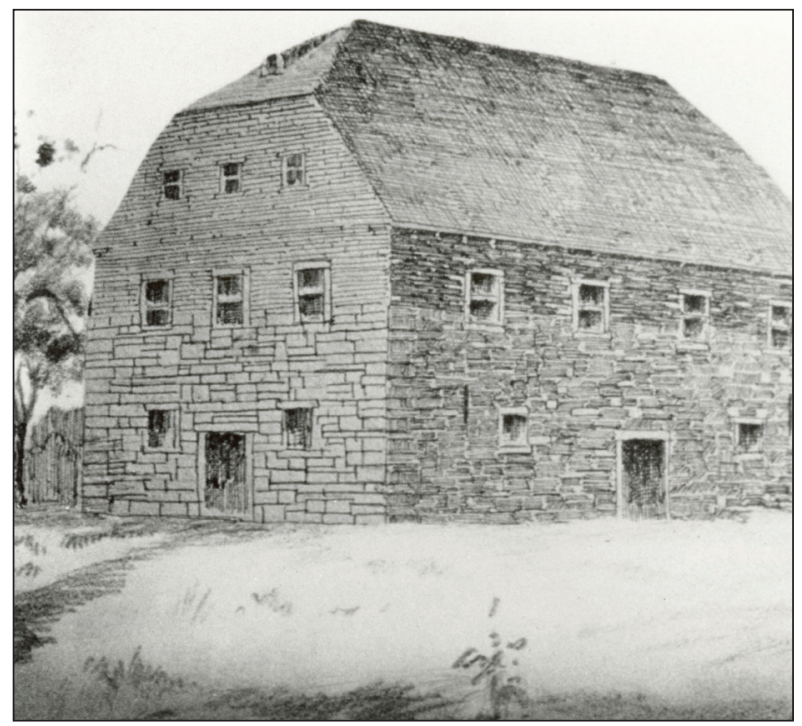

Harmonist granary (the "Old Fort") at New Harmony, David Dale Owen's laboratory. various points of geological importance in the neighborhood" (Hendrickson, 1943, p. 69). Soon afterward Owen and Joseph Norwood, who later became State Geologist of Illinois, explored central Kentucky, apparently on their own and without other financial backing.

In 1854 the Kentucky Assembly approved a geological survey of that state, and the governor selected Owen to head it. In 1857 the governor of Arkansas offered Owen appointment as State Geologist for a first survey of that state, and Owen accepted the appointment after arranging with the governor of Kentucky to continue direction of the Kentucky survey without salary.

During the years of Owen's involvement in surveys of the territories and of Kentucky and Arkansas, efforts had continued to resume state-supported geologic work in Indiana. These efforts were successful in 1859, when the General Assembly authorized a Geological Survey under the supervision of the State Board of Agriculture and created (anew) the office of State Geologist. The board wished no one but Owen to supervise the work, and Owen accepted the assignment with the provision that his brother Richard would begin the study and pursue it until the Arkansas survey was completed. Richard Owen conducted a 65-day field season beginning in September and returned to New Harmony with 1,000 pounds of specimens. David Dale Owen reported to the State Board of Agriculture in Indianapolis in January 1860 on the progress of the work and plans for the following season, during which Richard Owen concentrated principally on the Coal Measures.

David Dale Owen had in the meantime further complicated his life by undertaking the construction of a new laboratory in New Harmony to serve the former functions of the old granary. He designed every aspect of the new building and supervised the construction.

Since the 1854 field season in Kentucky, he had been in poor health from bouts with some fever, and to these miseries were added those of acute rheumatism in October 1860. His biographer, W. B. Hendrickson, recounted (1943, p. 130-131) that Owen was bedfast and dictating the second Arkansas report to two secretaries. His personal physician warned him, "Doctor, if you go on thus you will die in a week." Owen's reply was, "I only want 13 days to finish." He continued dictation until three days before his death on November 13,1860 , at the age of 53. J. P. Leslie wrote to James Hall, "Poor Owen is dead, suicide!" which in a sense was true; Hendrickson observed, "David Dale Owen literally worked himself to death." 


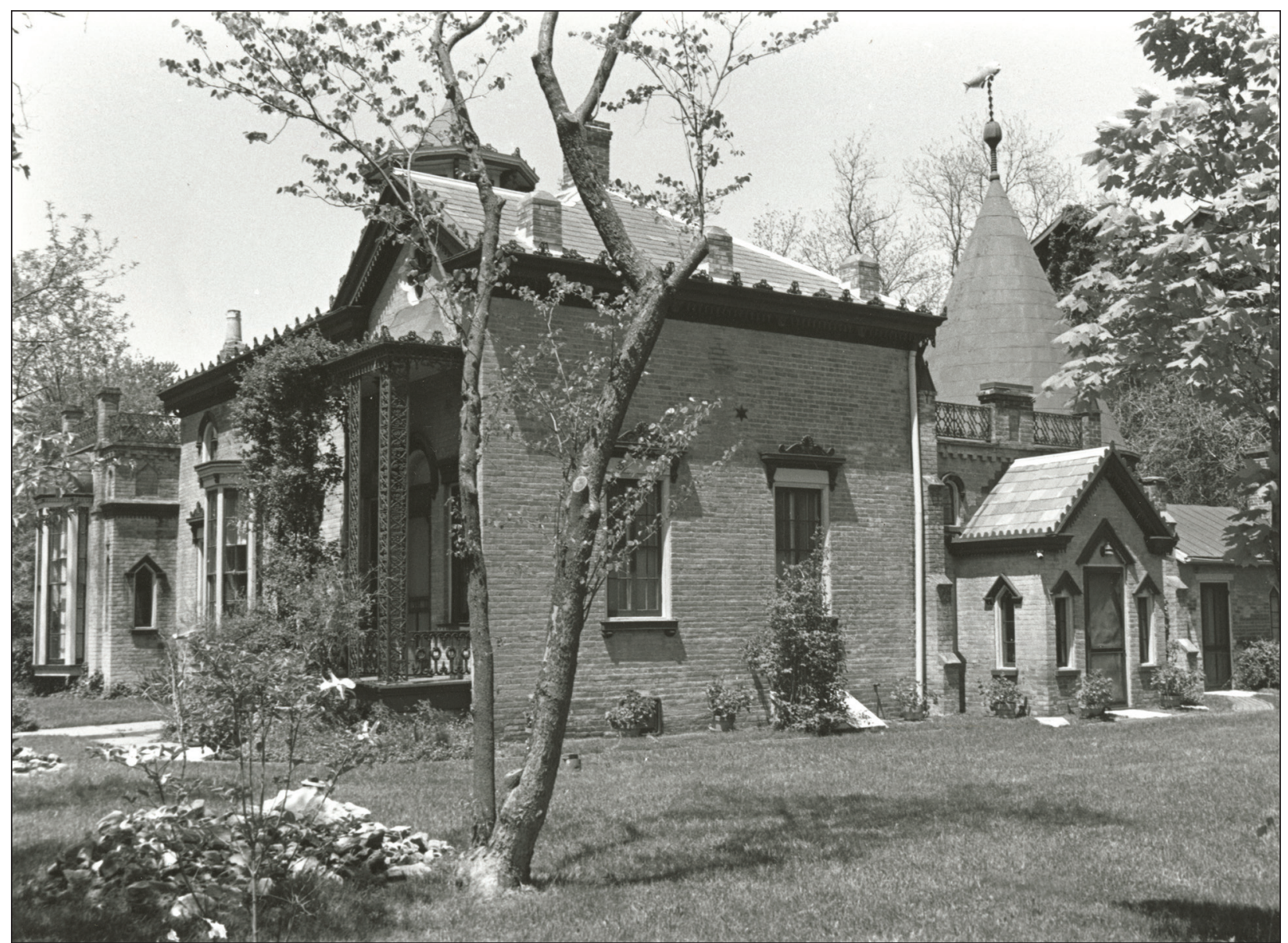

David Dale Owen's fourth laboratory, built in 1859; the south end of the third laboratory, with a gable roof installed after a fire, is on the right.

\section{THE SECOND INDIANA SURVEY}

The second Indiana survey was completed by Richard Owen (1862), who was appointed State Geologist to succeed his brother. That the report, except for sections credited to Dr. Robert Peter, Prof. Leo Lesquereux, and Mr. J. P. Leslie, was largely Richard Owen's work is clear.

It should be noted that the two Owen surveys of Indiana conducted in 1837 to 1839 and 1859 to 1861 were in charge of a person rather than an organization. The funds for salary and expenses were paid through the budget of the Indiana Department of Agriculture, but David Dale and Richard Owen were free to hire whom they chose and be reimbursed for such expenses as they incurred, all within the dollar limit set by the enabling legislation.

On March 5, 1869, the Indiana General Assembly approved an Act providing for a Geological Survey and for the collecting and preserving of a Geological and Mineralogical Cabinet of the Natural History of this State, and creating the Office of the State Geologist, defining his duties, fixing his salary, and appropriating a sufficient sum of money to defray the necessary expenses of said Survey and for the collection and preservation of said Cabinet.

A new organization named the Department of Geology and Natural Science was established under the State Board of Agriculture, and Edward Travers Cox of New Harmony, a former associate of the Owens in various investigations, was named to head it, which he did for ten years, turning out ten annual reports published in seven volumes.

In 1879 legislation replaced the Department of Geology and Natural Science with a Department of Statistics and Geology. The salary of the State Geologist was lowered appreciably, as were the operating funds, and the duties were vastly expanded in nongeologic directions. Cox declined to continue, and John Collett, who had served as an assistant to Cox, was appointed and accepted. The new department lasted only two years, and in 1881 a Department of Geology and Natural History 


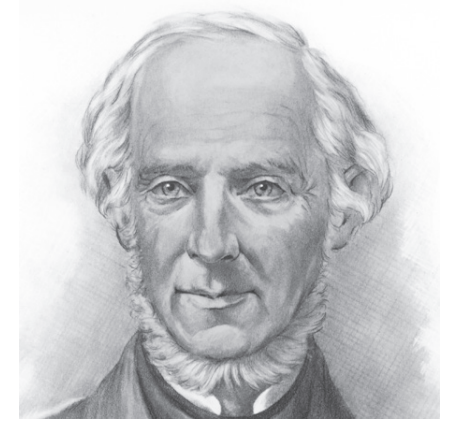

Richard Owen, State Geologist, 1860-61.

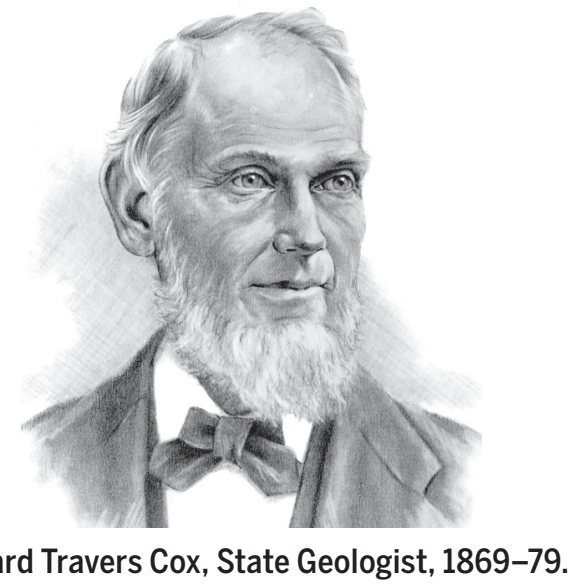

was established. The term of appointment for the State Geologist was increased from two to four years. Collett continued in the position and turned out four annual reports.

Between 1869 and 1884, Cox and Collett had been dutifully listed as faculty members ex officio in the Indiana University catalogs without, so far as can be determined, having any involvement with the academic program.

Collett had been appointed to a two-year term by a governor who was a Democrat and a four-year term by the next governor, who was a Republican. A Democrat was elected governor in 1884 and appointed Maurice Thompson, who was a civil engineer and a successful author of fiction. He served only three years, from 1885 to 1888 . Two annual reports were issued during his tenure, and their geologic high points were new information concerning the thickness and character of the glacial drift, confused interpretation on the part of both Thompson and his assistant S. S. Gorby on the Niagaran reefs at the surface in northern Indiana, and the first accounts of the discovery of natural gas.

Thompson resigned before his term was completed, but after the election of 1888 the outgoing governor appointed Sylvester S. Gorby to fill the position. The new governor was a Republican, but the legislature remained firmly in the hands of the Democrats, and they set out to remove the governor's veto, abolished the Department of Geology and Natural History and the appointive office of State Geologist connected therewith, and established a new Department of Geology and Natural Resources, to be headed by a Director elected by the General Assembly. The legislature then appointed (not elected) Gorby "State Geologist." The new governor refused to recognize the act, and in March 1889 he appointed Collett to the post. Gorby declined to give up the office, and Collett apparently did not press the issue. In November the Supreme Court held that the legislature had no power to create an office and then fill it; the choice must be made by the governor or by popular election. Gorby managed to hold on until 1890 , when he was nominated by the Democrats and won the election.

The sixth State Geologist of Indiana, Willis Stanley Blatchley, was, in this writer's judgment, the greatest builder of program strength during the first century of the period covered by this study. He served from 1895 to 1910 - a longer period than any of his predecessors; time in office is surely a factor in establishing a program, but from the beginning of his tenure he demonstrated an unusual ability to identify and attract capable scientists, either to work for his organization or to publish the results of their investigations in the annual reports without being paid. The authors of the papers in annual reports issued during the Blatchley years constitute a merit list in geology. Blatchley was primarily an entomologist rather than a geologist; he established an enviable record of productivity with meager funds - the sign of an able administrator.

In the election of 1910, Blatchley was defeated by Edward Barrett, who served two four-year terms during which an increasing proportion of the published

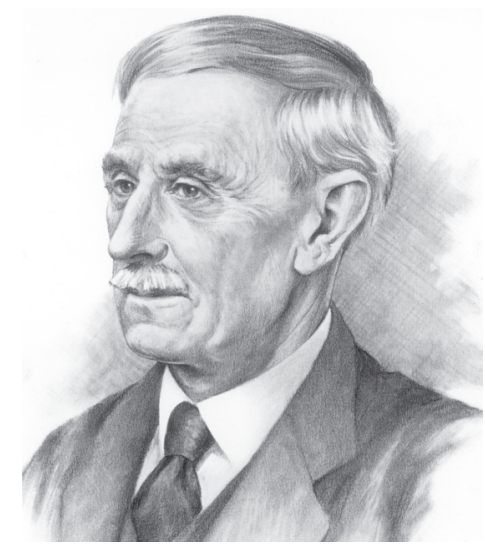

Willis Stanley Blatchley, State Geologist, 1895-1910. 
work was in the form of county soil surveys, and this concluded a period of 28 years during which the office was elective.

Indiana state government underwent massive changes when a reorganization act was passed early in 1919 and took effect in April of that year. The Indiana Department of Geology and Natural Resources was abolished, and its responsibilities were assigned to a Division of Geology within a newly created Department of Conservation. Because the office of State Geologist was elective, it had to be placed on the ballot in 1918, even though it was virtually certain to terminate. The victor was Louis Roark, who was a new faculty member in the Department of Geology at Indiana University. He never served in the office to which he was elected. In the new arrangement the Division heads were appointive, and the governor designated William M. Logan, who had joined the Indiana University faculty with the 1916-17 academic year, to head the Division of Geology concurrently with his academic duties. With Logan's appointment there began the closest alliance between the University's Department of Geology and the state program that has ever existed. An office that managed such regulatory matters as drilling permits and plugging of wells continued in Indianapolis, but the office of the State Geologist was on the Bloomington campus, and faculty members and students carried out most of the investigations, many of them through summer field parties. The annual reports that had been issued for so many years and that had included, in single-volume bound form, all the year's publications became brief administrative accounts of the year's activities; scientific papers were issued, generally separately, within a numbered Department of Conservation series that included publications from other divisions. An exception was the Handbook of Indiana Geology (Logan, 1922), which contained six parts and ran to 1,120 pages. Included was C. A. Malott's "The Physiography of Indiana," in which Malott named and described seven bedrock physiographic regions that cover all of southern Indiana south of the Wisconsin glacial boundary and extend, recognizable from subsurface records, beneath the thickening glacial drift to the north. Malott preferred to term himself a physiographer rather than a geomorphologist. He had the unusual ability to describe terrane in a manner that made it recognizable to persons seeing it for the first time.

Another example of the University/state agency cooperative effort referred to is the Indiana Department of Conservation Publication 75, Geology of the Silurian Rocks of Northern Indiana (1928), one of a triumvirate of papers by E. R. Cumings, Chairman of the Department of Geology at the time, and his graduate student Robert R. Shrock. The three papers were fundamental works on reefs and their environment, and they have joined the ranks of classics. Reef geology, largely neglected during much of the time since Darwin's day, was principally of academic interest at the time of the Cumings and Shrock studies, but its significance to petroleum geology brought it to the forefront in the 1940s.

Logan retired after the 1935-36 academic year, and Ralph Emerson Esarey became State Geologist and served until 1945. During his tenure in office, two external events greatly affected the Survey and its activities. A major new oil play developed in the Illinois Basin and spread to the Indiana portion by the latter 1930s, and subsurface information became available at a rate that made it difficult to record and impossible to digest. The Indianapolis office from which the Survey's regulatory functions were administered was hard pressed, and the entry of the United States into World War II in 1941 caused constant change, and ultimately diminution, of staff.

\section{THE CHARLES F. DEISS YEARS}

Near the end of World War II, President Herman B. Wells of Indiana University proposed to the Indiana Department of Conservation that the Geological Survey and the Department of Geology be directed by a single head and that the Department of Geology faculty constitute most of the professional staff of the Survey. Research associateships and funds for field expenses were to be supplied through the Conservation budget. The search for a new head resulted in the selection of Charles F. Deiss, then head of the Department of Geology at Montana State University at Missoula, to be Chairman and State Geologist. He arrived in 1945 and began immediately to build staff. The Geological Survey grew under his direction to a staff of about 50 in a dozen years. At his request the Survey was freed by legislative act in 1947 of regulatory authority and duties related to the petroleum industry, and a separate

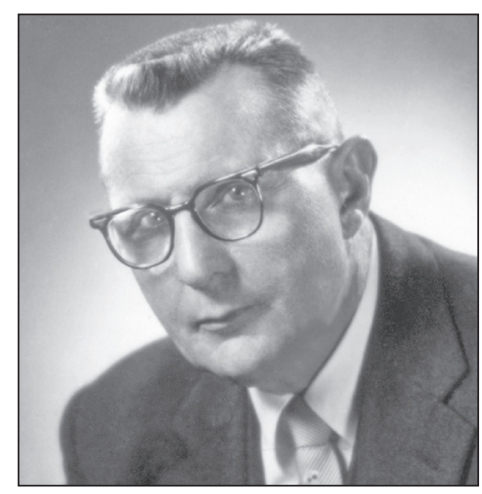

Charles Frederick Deiss, State Geologist, 1945-59. 
Division of Oil and Gas in the Department of Conservation was established.

The plan to use departmental faculty as professional staff for the Survey proved, after about a year, only partially successful, and Deiss moved the organization systematically toward a staff of its own. By 1947, the Survey consisted of a Petroleum Section with two professional employees and had an excellent drafting and photographic unit. The mission was to establish a program in industrial minerals and head a new section with that name. Geochemistry laboratories were set up in 1948 and section status was given to the field of geochemistry in 1952. A publications office, a Coal Section, and a Geophysics Section were established at the beginning of the 1950s.

The name of the organization was changed, by act of the General Assembly, from Division of Geology to Geological Survey in 1951. Paleontology and Glacial Geology Sections were established during the 1950s and fused into a Geology Section in 1959.

\section{THE JOHN B. PATTON ERA}

The rapid expansion of both the Geological Survey and the Department of Geology during the latter 1940s and the 1950s had posed imperative space needs to which Indiana University responded valiantly. The two organizations were headquartered in Owen Hall but occupied parts or all of 11 buildings when consolidation into the Geology Building took place in 1962 for the Department and 1964 for the Survey.

At the beginning of the 1965-66 fiscal year, the Survey's parent organization, the Department of Conservation, was fused with the Indiana Flood Control and Water Resources Commission into a new Indiana Department of Natural Resources that was divided into two Bureaus, and the Geological Survey became a division of the Bureau of Water and Mineral Resources. With each expansion of the chain of command, a unit such

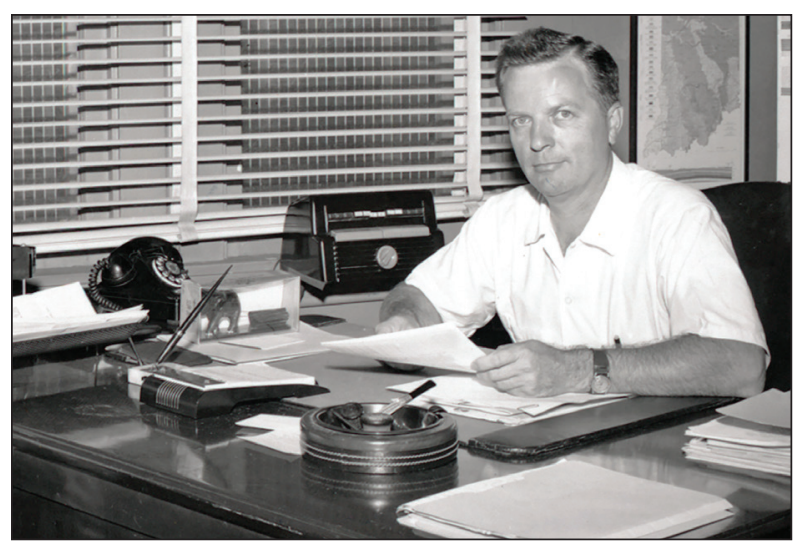

John B. Patton, State Geologist, 1959-86.

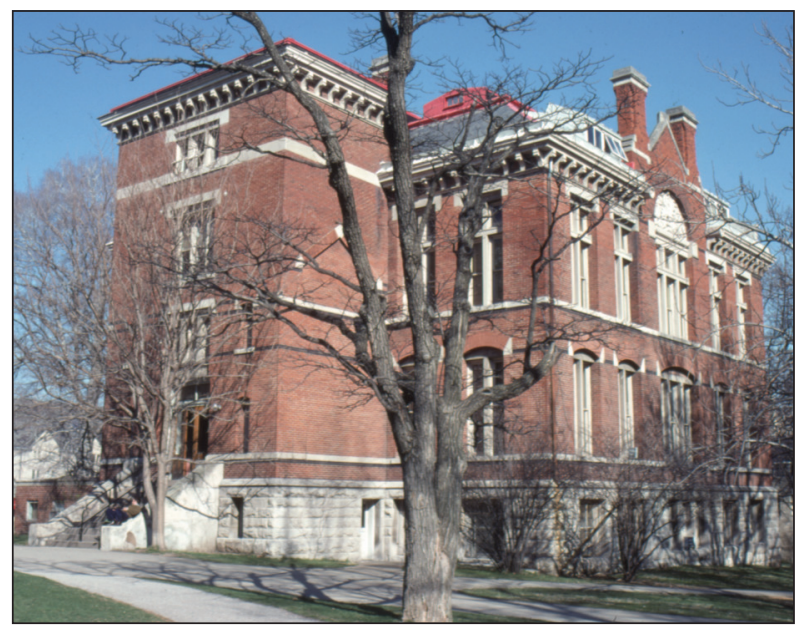

Owen Hall, the oldest building on the Bloomington campus of Indiana University, housed the State Geologist's office and some of the Geological Survey's working quarters from 1937 until 1962.

as the Geological Survey was farther removed from top management of state government.

When Deiss died in 1959, John B. Patton became State Geologist and Director. The Coal and Industrial Minerals Sections were joined in 1975. During that period the Indiana Survey received widespread recognition for its quality research and service to the mineral industry of Indiana.

The Indiana Geological Survey (IGS) has no archive of its own for the period preceding Charles Deiss's administration, which began in 1945. During much of the 28 years that the office of State Geologist was elective, transfer of records between succeeding officeholders was probably minimal, although it is apparent that projects initiated during the Blatchley administration were completed during his successor's tenure.

The absence of any such archive adds difficulty to the compilation of an accurate organizational history, but fortunately Blatchley (1917) reviewed the period before 1916 extremely well and did it at a time when the documentation was more feasible than it became later. At some date the Indianapolis office of the Geological Survey and an accompanying museum display were moved from the lower floor of the State Capitol. By the early 1930s the offices were housed on an upper floor and at the rear of the Indiana State Library Building. The whereabouts of the earlier exhibits, and perhaps retired files, was unknown to staff from the 1930s until the 1950s, when a structure west across Senate Avenue from the Capitol, at that time called the Department of Highways Annex, was razed to make way for a new State Office Building. After demolition was well underway, the administration of the Survey was notified 
that a sealed off basement had turned out to contain geologic materials. During a hasty rescue expedition, they retrieved, between swings of the wrecking ball, some cubic yards of tumbled debris - fossils, mineral rock specimens, labels (none still with the object that they were to identify), books, and miscellaneous papers. All had been under water, and few written words could be deciphered. Much of the material had already gone to a landfill, but the part that was recovered and examined suggested that little could have been gained if the entire mass of debris had been salvaged.

Blatchley's account (1917) of what he termed "A Century of Geology in Indiana" was reviewed by Melhorn (1967) in a paper that also contained coverage of an additional 50 years.

Surely the most significant event in the Survey's history up to this point was the decision, toward the close of World War II, to unite the geologic program for the State of Indiana with the academic geologic effort at Indiana University. The time was right, and the choice of a person selected to head the dual effort was fortunate. In an amazingly short while, two faltering programs were on the move. Although that part of the concept that would have used faculty as professional Survey staff was less than fully successful, the Department of Geology included persons with expertise in fields that the Survey needed to pursue. The Survey, in turn, soon had specialists in fields not immediately among the offerings of the Department's curriculum. Field and laboratory apparatus were available for sharing, without loss to the nominal owner, and some items that could not be afforded by either partner could be acquired jointly, always with fiscal accountability.

As an example, by 1948 the Geological Survey, which previously had essentially no geochemical capabilities, shared a first-rate wet chemistry laboratory and an analyst with the Department of Geology, had its own spectrographic facilities and spectrographer, and had access to an X-ray diffraction laboratory in the academic department. The IGS Geochemistry Section was established in 1952 and soon had its own X-ray equipment and other analytical tools.

The Indiana Geological Survey was one of the first state geological organizations to make extensive use of the geophysical techniques that were becoming so rapidly available to the civilian world in the immediate postwar period. In 1948, Deiss arranged a cooperative program with the U.S. Geological Survey (USGS)to make an aeromagnetic survey of the Kentland region of disturbed rocks in northwestern Indiana. Although the results of this preliminary survey were inconclusive, the method showed promise for providing information about the igneous and metamorphic rocks that form the basement complex of the state. As a result, a survey of the entire state was made by the USGS on a matching-funds basis, and Indiana became the first state to have total aeromagnetic coverage. County maps showing these data were published at a scale of 1 inch to the mile.

In 1950, beginning a program of close cooperation of the geophysics efforts of the IGS and the Indiana University Department of Geology, a field party began a seismic-refraction survey of the thickness of glacial deposits in northern Indiana. A Geophysics Section was formed in 1951 and grew rapidly to include four full-time geophysicists. Seismic-refraction surveys continued and were expanded to include investigations of preglacial drainage systems in connection with water resource studies and mapping of bedrock configurations at dam sites. In all, the section obtained refraction data from nearly 12,000 seismic shots.

The section also worked to supplement the interpretations of the aeromagnetic data. Magnetometer and gravity surveys were made over some of the most striking of the aeromagnetic anomalies, and a gravity survey of the entire state was completed in 1953.

The section obtained a 24-trace reflection seismograph in 1953 and began surveys to map the depth to basement rocks in southwestern Indiana. This program provided some new insight into the framework of the state, but it also afforded the final impetus for acquisition of drilling equipment. In order to detonate the amount of explosive needed for seismic-reflection surveys, a drilling rig was required.

The seismic program was expensive to operate, and reflection shots were made only during a few weeks each summer. During the remainder of the year the drilling rig worked away at the accumulated problems for which cores or perhaps cuttings could provide conclusive answers. When the first rig burned in 1957 as a result of a natural gas blowout, it was replaced by larger and more effective equipment. During the 35 years of the IGS coring program, more than 400 logged stratigraphic drill holes provided a fairly clear picture of the shallow bedrock geology of Indiana - even under the four-fifths of the state covered by glacial deposits. Geologists of the Coal and Industrial Minerals Sections also made effective use of the drill to define in detail the mineral resources of the state; this was of great value to the mineral industries.

Without doubt the mineral industries were supportive of the Geological Survey, and the Survey has in turn assisted countless firms and individuals in developing mineral resources. Credit was formally given to the Geological Survey for the major gypsum operations 
in the state and for initiating the production of quartz pebble and high-silica sand.

The history of statewide geologic mapping in Indiana through 1972 was summarized by Patton and Henry Gray (1973), and significant advances followed. The need for a new state map showing bedrock distribution was recognized from the beginning of the Survey's postwar rejuvenation. At the annual meeting of the Association of American State Geologists (AASG) in Austin in 1958, the Army Map Series quadrangles covering $1^{\circ}$ of latitude and $2^{\circ}$ of longitude at 1:250,000 scale were on display as the basis for California mapping, and they appeared to offer a mechanism for remapping the Midwest in manageable units that would ultimately cover the entire state and its surrounding areas and, at the same time, eliminate stateline faults and discrepancies in stratigraphic terminology.

Late in 1958 Charles Deiss convened a meeting in Bloomington attended by the State Geologists of Illinois, Kentucky, Michigan, and Ohio and by other staff members of those organizations. The result was agreement for a cooperative effort in which the geological surveys of our surrounding states would provide coverage of their portions of the eight $1^{\circ}$ by $2^{\circ}$ quadrangles that covered all of Indiana except for a few townships in the Evansville quadrangle and small areas in the Paducah and Belleville quadrangles that could be attached as extensions to the Vincennes sheet. It was agreed that both bedrock and unconsolidated deposits would be shown, and later it was decided that bedrock would be in pattern and unconsolidated deposits in color. The Illinois and Michigan Surveys were able to contribute their coverage. The four eastern sheets were completed after the western sheets were done, and by then changes in the fortunes and available staff time of the Ohio Survey occasioned its withdrawal from the cooperative arrangement after only part of the glacial geology and none of the bedrock compilation for the eastern sheets had been submitted, but Jane Forsyth continued her assistance with the Ohio glacial deposits after she left the Ohio Survey and joined the faculty of Bowling Green State University. She compiled the coverage of the glacial geology for the Fort Wayne, Muncie, and Cincinnati quadrangles. Bedrock coverage for the Ohio portion of the eastern sheets was compiled by the IGS.

At the outset of the project, it appeared that the Kentucky coverage would be assured through the massive contract into which Kentucky had entered with the USGS to map the entire state on 7.5-minute quadrangles, but many of those quadrangles in the Ohio River region fell late in the schedule, and ultimately the maps were printed without Kentucky coverage on the Cincinnati,
Louisville, and Vincennes quadrangles. In August 1972 the Survey displayed the eight joined quadrangles (one of them a days-old color proof) as a single huge map at the International Geological Congress in Montreal. After the first sheet - the Indianapolis quadranglewas issued, the Survey printed three versions of each a composite that showed both bedrock and unconsolidated materials and color versions of bedrock and unconsolidated deposits separately. A revised edition of the Indianapolis quadrangle (1979) offered all three versions. These Regional Geologic Maps, as the series was named, served many needs. Subsequent maps at 1:500,000 scale show bedrock topography (Gray, 1982a, 1982b), thickness of unconsolidated deposits (Gray, 1983a, 1983b), and bedrock (Gray, Ault, and Keller, 1987).

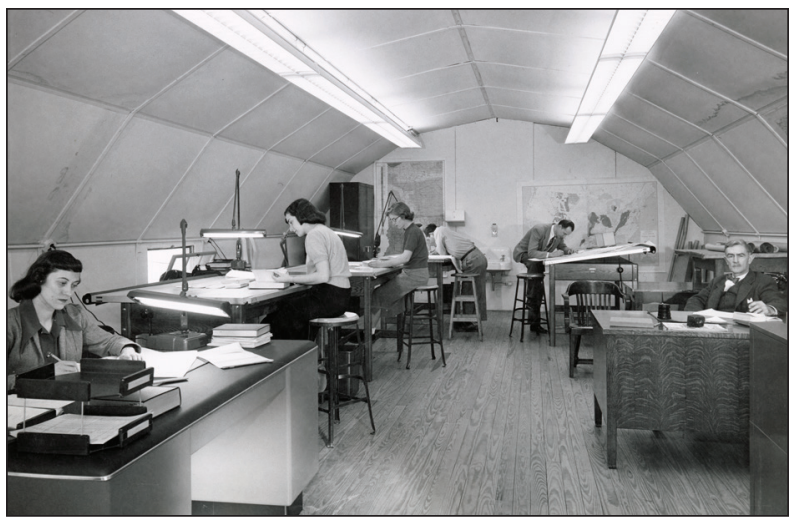

In the early 1950s, several offices of the Indiana Geological Survey were housed in Quonset huts. Photo from around 1950.

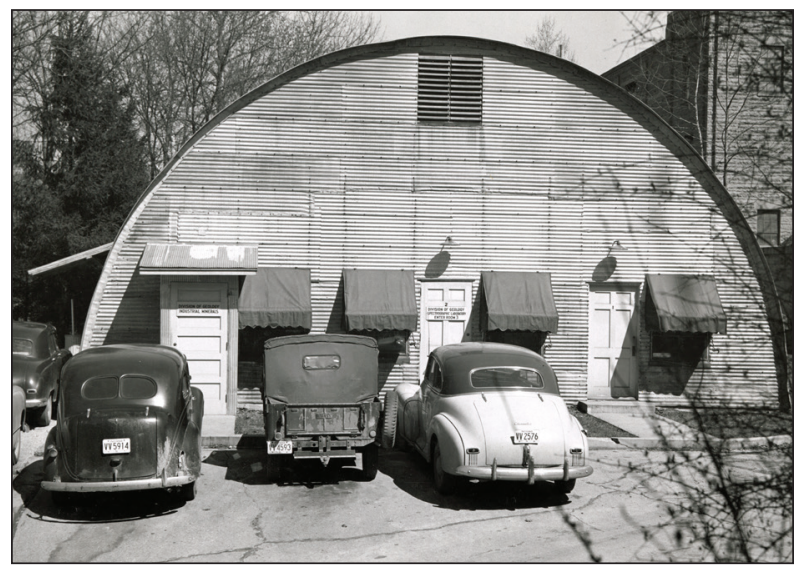

Exterior of the Quonset hut located near Woodburn Hall. The signs on the doors read: "Division of Geology Industrial Minerals" and "Division of Geology Spectrographic Laboratory-Enter Room 3." Photo from around 1950. 
In the period following World War II, President Herman B Wells of Indiana University viewed the Geological Survey as a service and research arm of the University-a grassroots association with Indiana's populace and economy-as well as a division of state government, and both he and the University administration of the time were interested in the Survey's program, growth, and financial support. With the University's backing and in harmony with the Indiana Conservation Commission and the Department of Conservation, the Geological Survey grew to employ approximately 50 staff members by the early 1960s.

When it became apparent, in the middle 1950s, that entirely new quarters were the only satisfactory answer to the pressing space needs of both geologic units, a single building was initially planned, but the University was able to budget funds for new academic construction before the Department of Conservation was successful in obtaining support for Geological Survey quarters. As a result, the academic part of the Geology Building was completed and occupied in 1962 a month before ground was broken for a wing to house the Geological Survey. For both organizations the new space, built for the purpose in a way that existing space could never have been remodeled to duplicate, changed the pace and quality of professional life. To have the entire staff of the Geological Survey in a single and scientifically luxurious structure instead of attics, cellars, old residences,

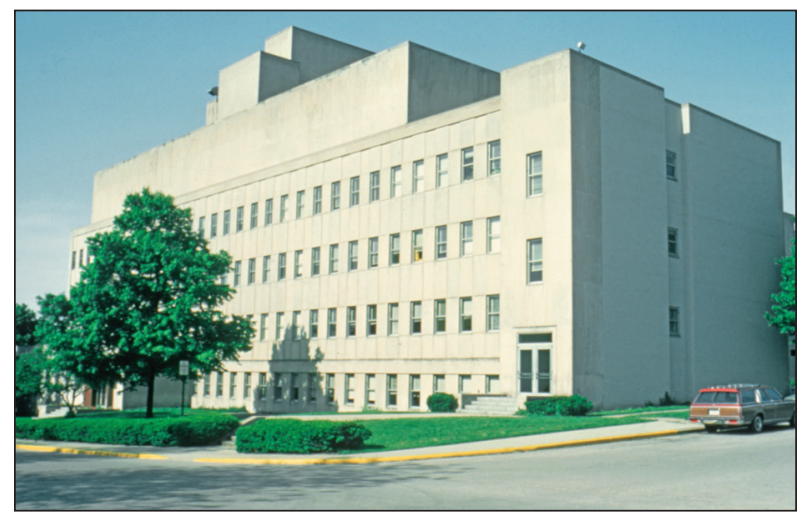

Geology Building on the Indiana University campus in Bloomington; only the Geological Survey wing is shown.

and Quonset huts and other temporary structures, as well as some excellent space assigned generously by the University, permitted a new degree of coordinated productivity.

In 1947 a severance tax of 1 percent well head value was imposed on Indiana oil and gas production, and the revenues were paid into a dedicated fund to support the Geological Survey, a newly established Division of Oil and Gas, and the costs incurred by the Indiana Department of Revenue in administering the tax program.
In its early years, the severance tax supported quick growth in the Survey, but it seemed discriminatory to tax a single one of the state's mineral industries, and Patton never favored it as the source of funding. The time came when Indiana oil production diminished to the point that the yield of the severance tax would not finance the existing programs of the IGS, and neither the state budget agency nor the General Assembly was inclined to supplement from the General Fund without a battle. There were good years and bad ones, the poorest of which resulted in a fiscal-year appropriation of 1 dollar to support the Survey-rather worse than no appropriation at all, as it revealed intent. Somehow the Survey survived, and in time high oil prices revived the yield of the severance tax for a period, but not for long. During those years, Patton tried to persuade the Department of Natural Resources to shift the Survey's funding request to the General Fund, but the answer was always that it was not desirable to rock the boat.

Under the terms of the agreement effectuated in 1945 between the Indiana Conservation Commission and Indiana University, the Chairman of the University's Department of Geology was to serve also as State Geologist, and Charles Deiss occupied this dual role from 1945 until his passing in 1959, as did John Patton from then until 1971. By the 1960s both programs had reached a level that merited a full-time head, and in 1966 Patton recommended review of the arrangements for the purpose of separating the administrative positions. To facilitate consideration without any embarrassment concerning what to do with the incumbent, Patton proffered his resignation, but it was not accepted, and the situation remained the same through four changes in the deanship of the College of Arts and Sciences. Patton offered annually to resign and clear the way, but in 1971 the change was effected and an Acting Chairman was named for the academic department. Patton continued as a faculty member, teaching a course each semester and directing graduate student research.

\section{THE HESTER YEARS, 1986-1998}

Norman C. Hester served as the thirteenth State Geologist and Director of the IGS and as a faculty member in the Indiana University Department of Geological Sciences from July 1986 through June 1998. During his tenure as State Geologist, he promoted the importance of geology to state, federal, and local officials as a vital component of the decision-making process. He fostered improved communications and cooperation among the state geological surveys of Indiana, Kentucky, Illinois, and Ohio, with the Illinois Basin Consortium (IBC) being the most notable example of those efforts. 


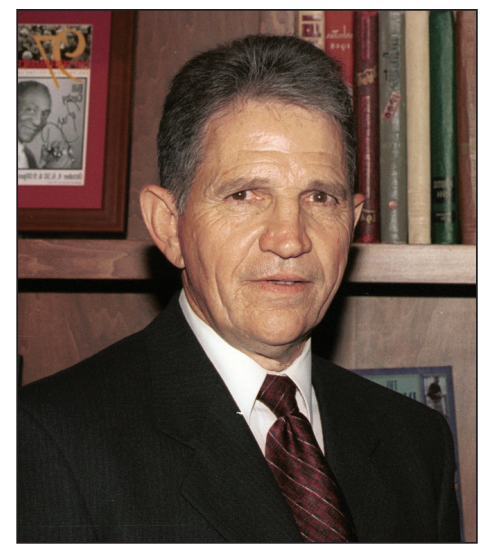

Norman C. Hester, State Geologist, 1986-1998.

Working with contacts within the USGS and members of AASG, Hester laid the groundwork for a variety of significant contributions to the geologic mapping of the United States, funded under the umbrella of the National Geological Mapping Act. Beginning in 1992, the National Cooperative Geologic Mapping Program (NCGMP) was created within the USGS, whose purpose was to build the National Geologic Map Database, co-managed by the USGS and AASG. The STATEMAP part of the NCGMP brought funds to the survey to create large-scale surficial and bedrock geologic maps. The National Geologic Mapping Act has twice been reauthorized and continues to support mapping efforts in Indiana and across the nation.

Under Hester's leadership, the IGS earned recognition for its contributions to the three-dimensional portrayal of nonlithified materials in various northern Indiana counties, for work on the performance of geological materials to earthquake-induced ground shaking in the greater Evansville area, and for aquifer characterization studies throughout the state. He was instrumental in establishing the Central United States Earthquake Consortium-State Geologists, an active program involving the cooperative development of a variety of derivative maps by staff of eight midwestern state surveys; these maps illustrated elements of seismic hazards including ground shaking amplification and liquefaction. He continued his service to this group on contract with the USGS as the principal liaison between the state and federal surveys.

The Central Great Lakes Geologic Mapping Coalition was formed in the late 1990s, and consisted of the state geological surveys of Illinois, Indiana, Michigan, and Ohio working in partnership with the USGS. Its mission is to make three-dimensional geologic maps that characterize unconsolidated deposits of the last glacial age and near-surface bedrock deposits and to delineate, interpret, and determine the viability of groundwater resources. Later, the coalition's name was changed to the Great Lakes Geologic Mapping Coalition to reflect the addition of the surveys of Minnesota, New York, Pennsylvania, Wisconsin, and the Canadian province of Ontario.

Working with the Department of Commerce, Hester negotiated a partnership among coal-fired utilities, the USGS, and collaborators within the Illinois Basin Consortium to gather new subsurface information and to collect existing coal quality data from producers within the Illinois Basin, a broad structural feature encompassing Illinois, much of Indiana, and western Kentucky. The result of these efforts produced a modest resurgence of interest on certain low-sulfur coals in the Illinois Basin.

Perhaps his single greatest contribution to the long-term health of the IGS, Hester made a case for and received support from throughout state government to transfer the IGS from the auspices of the Department of Natural Resources to Indiana University as a research institute under the administration of the Indiana University Office of Research and the University Graduate School. In 1993 this change, established by state statute (Indiana Code 21-47-2), consolidated budgetary and management control under one roof and served to insulate the Survey from upsets experienced by state agencies as the result of changes in elected officials. However, the new connection with Indiana University had one disadvantage: the loss of the 1 percent petroleum tax from the Survey's coffers. With the loss of the petroleum severance tax, reliance on outside grants and contracts to fund the operation and projects of the Survey had been gradually increasing since the mid-1970s. The dependence upon outside funding intensified during the 1980s and 1990s.

The digital age blossomed during the Hester years as mechanical ways of writing, drafting, and mapmaking were replaced by computer-driven applications.

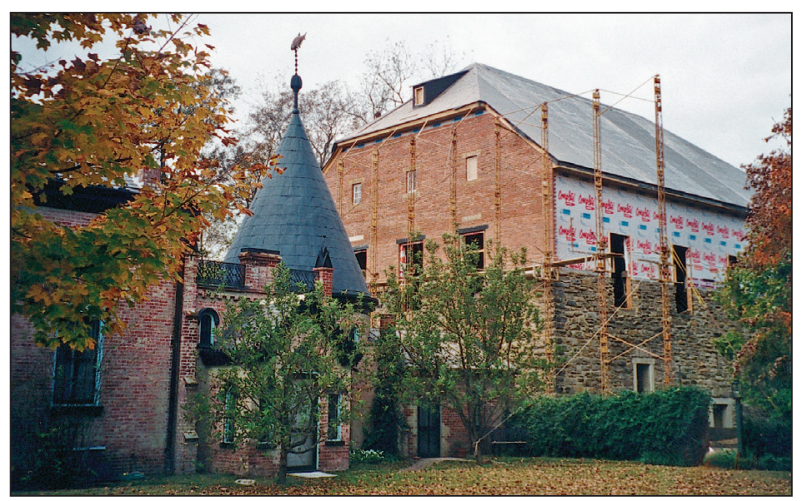

The Rapp-Owen Granary in New Harmony underwent extensive reconstruction and restoration from 1997 to 1999. Both Norman Hester and John Steinmetz were involved in supporting and promoting the reconstruction. 
The Survey embraced these changes creating an in-house network with file and printer sharing, document publishing, and geographic information systems replacing typewriters, typesetting, and map scribing. In 1995 the IGS published its first institutional website, which gradually changed the way the Survey disseminated information and data to the public.

\section{THE STEINMETZ YEARS, 1998-2015}

John C. Steinmetz became state geologist and director of the IGS in the fall of 1998. He previously served as director and state geologist for the Montana Bureau of Mines and Geology and adjunct professor of geology at the University of Montana-Missoula.

In 1998, the Center for Geospatial Data Analysis was formed when researchers from the Indiana Geological Survey and Indiana University Department of Geological Sciences combined their expertise and innovation to solve problems collaboratively. Its main mission was to address issues related to hydrology, the environment, and energy resources by applying geographic information systems (GIS) to solve complex problems having an inherent spatial component.

In 2000, Steinmetz actively campaigned for the IGS to be included in a contract to analyze the expansion of Interstate 69 northward from Evansville to Indianapolis, and staff members began compiling the GIS (Geographic Information System) Atlas for Southwestern Indiana. Partnering with the newly formed Geographic Information Office and the Indiana Geographic Information Council, the IGS expanded this interactive web map to include all of Indiana. Along with a redesign and greater geospatial coverage came a new name-IndianaMap. IndianaMap grew dramatically during the next decade to include nearly 300 data layers, more than 100 data partners, and a hefty 15 terabytes of storage.

John Steinmetz was aware of the need to hire and promote women in the geosciences. During his tenure at the IGS, he promoted female geoscientists to the ranks of director of the Center for Geospatial Data and Analysis and head of the Environmental Geology Section.

In 2004, the IGS ceased publication of its printed newsletter, GeoNews, and entered the digital world of e-newsletters. The newsletter, re-titled e-GeoNews, is published quarterly and is delivered via e-mail to more than 1,600 subscribers. In it, the IGS publicizes new research, advertises new publications, promotes upcoming events, highlights website content, and discusses staff transitions.

In 2003, the IGS joined a number of state geological surveys and other organizations to begin evaluating the potential for carbon capture and storage (CCS)

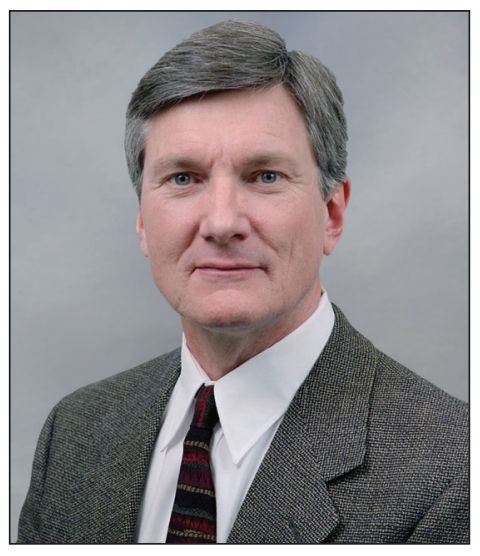

John C. Steinmetz, State Geologist, 1998-2015.

technologies to sequester greenhouse gas emissions from the atmosphere and safely store carbon dioxide in geologic reservoirs. With substantial support from the U.S. Department of Energy, the IGS has continued this work for nearly two decades and remains active in several research consortia and public-private partnerships that are advancing this technology in the U.S. and internationally. Current highlights include partnering on the \$50M US-China Clean Energy Research Center, Advanced Coal Technology Consortium project, and the $\$ 16.6 \mathrm{M}$ Carbon Storage Assurance Facility Enterprise (CarbonSAFE) Wabash project in Vigo County. CarbonSAFE Wabash would be the largest CCS project in the nation if it moves forward through the research phase and to operational status in the next three years.

In 2013, a U.S. Department of Energy-sponsored geothermal research project was the impetus that brought together sedimentologists, hydrogeologists, petroleum geologists, and GIS experts within the IGS to undertake a two-phase research project. One aspect involved inventorying and assessing the deep geothermal potential of the state - the creation of the Indiana Water Balance Network (IWBN), a series of field stations that monitor trends in water loss and gain for different components of the hydrologic cycle. Data of this kind are essential in developing geological and pedological models in the design of geothermal heat pump systems. The second phase involved collecting field data and determining the geothermal potential of shallower horizons representative of many soil types in Indiana. A series of maps depicting bedrock topography, the elevation of the bedrock surface, unconsolidated sediment thickness were derived from water-well records, seismic refraction records, petroleum-well records, stratigraphic test records, and engineering records (Naylor and others, 2016a and b). This high-resolution series of maps, the first in 34 years, is a valuable aid for water well drillers and foundation engineers. 
The Steinmetz years saw an initial increase in state appropriation, but by the early 2000 s, the survey and surveys nationwide experienced flat or declining budgets related to austere practices at state levels (Buchanan, 2016). The result at the IGS was the need for increased revenue from external grants to support research, the closing of the Geochemistry, Geophysics, and Industrial Mineral Sections, the combining of other sections (such as Coal and Petroleum), and the loss of much of the clerical staff, cartographers, and laboratory technicians. Full-time employment at the IGS declined to numbers not experienced since the early Deiss years.

Concomitant with the decline in support staff was the orphaning of many the survey's physical and evergrowing digital collections. To stem the loss of geological and geophysical data across the nation, the Energy Policy Act of 2005 established the National Geological and Geophysical Data Preservation Program (NGGDPP) to preserve and expose the nation's geoscience collections (samples, logs, maps, data) and promote their discovery and use for research and resource development. Steinmetz was instrumental in the development of the NGGDPP, and the IGS fully cooperated in the program through his tenure.

\section{TODD A. THOMPSON, 2015-PRESENT}

John C. Steinmetz stepped down as state geologist in the fall of 2015 and retired from the Survey in 2016. Todd A. Thompson, formerly IGS Assistant Director for Research, was named Director of the Indiana Geological Survey and State Geologist of Indiana. Unlike the two previous state geologists, Thompson was hired from within the Survey, having worked in and across various sections during his previous 30 years of employment.

The name of the Indiana Geological Survey was changed to the Indiana Geological and Water Survey (IGWS). The name change, codified in Indiana Senate Bill 416, took effect on July 1, 2017. The new name reflected a realignment of the Survey's missionto provide geological information and counsel that contribute to the wise stewardship of the water, energy, and mineral resources of the state. The name also pointed out the Survey's expanded efforts in the study and dissemination of information about the quality and quantity of Indiana's surface and groundwater.

Throughout the years of its existence, the Survey's organizational structure changed many times. In 2016, the various sections were phased out and a flatter institutional structure was adopted, mostly owing to the continued reduction in staff numbers. Instead of sections based on geological fields of study and section

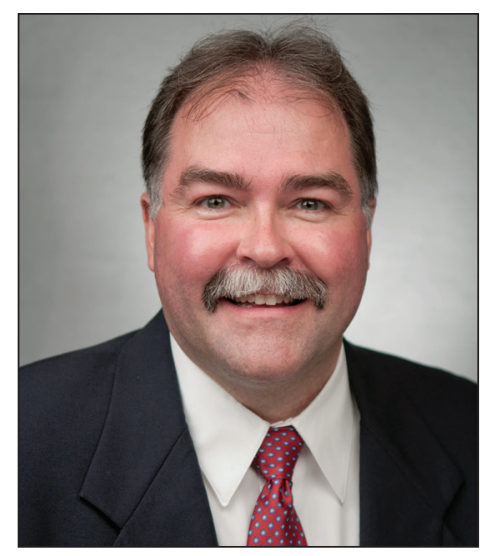

Todd A. Thompson, State Geologist, 2015-present.

heads who acted as middle managers, the administrators were now named the heads of three divisions: the Research, Information Services, and Finance Divisions.

The IGWS collections contain over 2,000,000 items comprising archival materials in paper, books, photographic print, photographic film, and digital formats, geologic samples and paleontological specimens, technological objects, and a large mural painting. The value of these collections has been valued at two billion dollars and is one of the top three most highly valued collections in Indiana University. As part of an increased awareness of the value of IGWS collections, an archivist and collections manager was hired in 2017 to ensure that the many objects were being properly catalogued and stored. The IGWS is at a critical stage in its history as the repository of geophysical specimens and data for the state of Indiana. The planned renovation of the Geology Building and the relocation of the Core Library and Testing Facility (see below) provided an excellent opportunity for IGWS to examine all of its facilities and programs and to redefine itself for improved operations in the $21^{\text {st }}$ century.

A study conducted in 2016 by Capstone Class 7933 in Indiana University's School of Public and Environmental Affairs conservatively estimated that the Survey has an annual economic impact of $\$ 110.4$ million on the state of Indiana. Completed as a class project, the study cited the Survey's online tools such as IndianaMap

\section{INDIANA GEOLOGICAL \& WATER SURVEY $10^{\circ}$ INDIANA UNIVERSITY}

In 2019, the IGWS adopted a new logo to represent the Survey's commitment to continued research for the benefit of the state of Indiana. 
and the Petroleum Data Management System as worth nearly $\$ 25$ million alone. The value of projects that would never be completed without the data provided by the IGWS was listed at more than \$56 million annually. This amount does not take into account the value of the extensive IGWS collections of cores, drill cuttings, well records, and other materials.

In 2019, the Survey moved to temporary quarters in downtown Bloomington while the Geology Building is being remodeled. The renovations, with updated heating and cooling facilities and expanded lab space and common areas, are expected to be complete in late 2020, with the IGWS returning to its longtime home on campus in early 2021. Indiana University also made the decision to move the IGWS Research and Teaching Core Repository from its building on campus to a temporary location. The Ideal Laundry building, which housed IGWS unconsolidated cores and samples, was demolished.

The Survey administration made the decision in 2018 to allow open access to its data and publications. As part of its commitment to this decision, hundreds of publications that previously were available at cost were scanned and are now accessible as free PDFs on the IGWS online bookstore. The Survey also moved from publishing its research in Special Reports, Occasional Papers, Miscellaneous Maps, and other series to making it freely available in an online open-access journalthe Indiana Journal of Earth Sciences - hosted on the Indiana University Libraries' website. The first issue was published in August 2019.

\section{REFERENCES}

Blatchley, W. S., 1917, A century of geology in Indiana: Proceedings of the Indiana Academy of Science for 1916, p. 89-177.

Brown, R. T., 1854, Geological survey of the State of Indiana, in Indiana State Board of Agriculture Annual Report 3, p. 299-332.

Buchanan, Rex, 2016, State budgets, geological surveys, and the new reality: Eos, v. 97, URL at https://doi. org $/ 10.1029 / 2016 \mathrm{EO} 059893$.

Cumings, E. R., and Shrock, R. R., 1928, The geology of the Silurian rocks of northern Indiana: Indiana Department of Conservation Publication 75, $226 \mathrm{p}$.

Fenton, C. L., and Fenton, M. A., 1942, Giants of geology: Garden City, N.Y., Doubleday \& Company, 318 p.

Gray, H. H., 1982a, Map of Indiana showing topography of the bedrock surface (color shading between 100 -ft. contour lines): Indiana Geological Survey Miscellaneous Map 35, scale 1:500,000.

$1982 b$, Map of Indiana showing topography of the bedrock surface (contour interval 50 feet): Indiana Geological Survey Miscellaneous Map 36, scale 1:500,000. 1983a, Map of Indiana showing thickness of unconsolidated deposits (color shading between 100-ft. contour lines): Indiana Geological Survey Miscellaneous Map 37, scale $1: 500,000$

1983b, Map of Indiana showing thickness of unconsolidated deposits (contour interval 50 feet): Indiana Geological Survey Miscellaneous Map 38, scale 1:500,000.

2018, Landmarks in Indiana geology: Indiana Geological and Water Survey Digital Information 19, URL at https:// igws.indiana.edu/IGSMap/LandmarksTimeline/.

Gray, H. H., Ault, C. H., and Keller, S. J., 1987, Bedrock geologic map of Indiana: Indiana Geological Survey Miscellaneous Map 48, scale 1:500,000.

Hendrickson, W. B., 1943, David Dale Owen-pioneer geologist of the Middle West: Indianapolis Historical Bureau Indiana Historical Collections, v. 27, 180 p.

Logan, W. N., ed., 1922, Handbook of Indiana geology: Indiana Department of Conservation Publication 21, 1,120 p.

Malott, C. A., 1922, The physiography of Indiana, in Logan, W. N., ed., Handbook of Indiana geology: Indiana Department of Conservation Publication 21, p. 59-256.

Melhorn, W. N., 1967, A century and a half of geology in Indiana: Proceedings of the Indiana Academy of Science for 1966, p. $103-115$.

Merrill, G. P., 1924, The first one hundred years of American geology: New Haven, Conn., Yale University Press, 773 p.

Naylor, S., Schumacher, J., and Sperl, B. J., 2016a, Map showing elevation of the bedrock surface in Indiana: Indiana Geological Survey Miscellaneous Map 94A, scale 1:500,000.

Naylor, S., Schumacher, J., and Sperl, B. J., 2016b, Map showing elevation of the bedrock surface in Indiana (contours): Indiana Geological Survey Miscellaneous Map 94B, scale 1:500,000

Owen, D. D., 1838, Report of a geological reconnoisance [sic] of the State of Indiana; made in the year 1837, in conformity to an order of the legislature: Indianapolis, Douglass and Noel, $34 \mathrm{p}$.

1839, Second report of a geological survey of the State of Indiana made in the year 1838: Indianapolis, Osborn and Willets, printers, $54 \mathrm{p}$.

1846, On the geology of the western states of North America (eastern Mississippi Valley): Geological Society of London Quarterly Journal, v. 2, p. 433-447.

1859 , Continuation of geological reconnoissance [sic] of the State of Indiana made in the year $1838, \ldots$ part second: Indianapolis, $69 \mathrm{p}$.

Owen, Richard, 1862, Report of a geological reconnoissance [sic] of Indiana, made during the years 1859 and 1860, under the direction of the late David Dale Owen, M.D., State Geologist: Indianapolis, H. H. Dodd and Company, 368 p.

Patton, J. B., 1979, Notable contributions of early Indiana geologists: Proceedings of the Indiana Academy of Science for 1978, p. 278-281.

1987, The sesquicentennial of geology in Indiana-1987, in Shaver, R. H., ed., A field guide and recollections-the David Dale Owen years to the present: Indiana Geological Survey Special Report 44, p. 5-21. 
1988, History of the Indiana Geological Survey, in Socolow, A. A., ed., The state geological surveys-a history: Association of American State Geologists, p. 117-133.

Patton, J. B., and Gray, H. H., 1973, Statewide geologic maps of Indiana: Proceedings of the Indiana Academy of Science for 1972, p. 303-309.

Patton, J. B., Millbrooke, Anne, and Nelson, C. M., 1983, The Harmony geologic legacy (Field Trip 11), in Shaver, R. H., and Sunderman, J. A., eds., Field trips in midwestern geology: Bloomington, Ind., Geological Society of America, Indiana Geological Survey, and Indiana University Department of Geology, v. 1, p. 225-243.

Reeves, J. R., 1922, Preliminary report on the oil shales of Indiana, in Logan, W. N., ed., Handbook of Indiana geology: Indiana Department of Conservation Publication 21, p. 1,059-1,105.

Socolow, A. A., 1988, The state geological surveys-a history: Association of American State Geologists, 499 p. 